\title{
Antimicrobial activity of Byrsonima species (Malpighiaceae)
}

\section{Daniele C. Michelin, ${ }^{1}$ Miriam Sannomiya, ${ }^{2}$ Maria E. Figueiredo, ${ }^{2}$ Daniel Rinaldo, ${ }^{2}$ Lourdes C. dos Santos, ${ }^{2}$ Alba R. M. Souza-Brito, ${ }^{3}$ Wagner Vilegas, ${ }^{2}$ Hérida R. N. Salgado ${ }^{* 1}$}

\author{
${ }^{1}$ Departamento de Fármacos e Medicamentos, Faculdade de Ciências Farmacêuticas, Universidade Estadual \\ Paulista, 14801-902 Araraquara-SP, Brazil, \\ ${ }^{2}$ Departamento de Química Orgânica, Instituto de Química, Universidade Estadual Paulista, 14800-900 \\ Araraquara-SP, Brazil, \\ ${ }^{3}$ Instituto de Biologia, Departamento de Fisiologia e Biofísica, Universidade Estadual de Campinas, Caixa \\ Postal 6109, 13083-970 Campinas-SP, Brazil
}

\begin{abstract}
RESUMO: “Atividade antimicrobiana de espécies de Byrsonima (Malpighiaceae)”. Espécies de Byrsonima, família Malpighiaceae, são popularmente conhecidas como "murici”. Existem várias propriedades atribuídas às folhas de espécies de Byrsonima incluindo febrífuga, no tratamento de disfunções gastrintestinais e doenças de pele. Neste trabalho avaliamos a atividade antimicrobiana dos extratos das folhas de Byrsonima fagifolia, B. basiloba e B. intermedia usando o método de difusão em disco. Os resultados obtidos mostraram que os extratos metanólicos das folhas apresentaram atividade antimicrobiana contra todos os microrganismos testados.
\end{abstract}

Unitermos: Malpighiaceae, Byrsonima, atividade antimicrobiana.

\begin{abstract}
Byrsonima species, family Malpighiaceae, is popularly known as "murici”. There are several properties attributed to the leaves of Byrsonima species including febrifuge, to treat gastrointestinal dysfunctions and skin diseases. In this work, the antimicrobial activity of Byrsonima fagifolia, B. basiloba and B. intermedia extracts obtained from the leaves were evaluated by using the disc-diffusion method. The results obtained showed that the methanol extracts of leaves had presented antimicrobial activity against all the microorganisms tested.
\end{abstract}

Keywords: Malpighiaceae, Byrsonima, antimicrobial activity.

\section{INTRODUCTION}

Medicinal plants are natural resources, leading to valuable herbal products, which are often used in the treatment of various diseases.

The Cerrado, a Brazilian savanna, comprises a very rich and characteristic flora. Many of these plants are used as natural medicines by the people living in this region to treat several tropical diseases including schistosomiasis, leishmaniasis, malaria, fungal and bacterial infections (Ferreira, 1980; Corrêa, 1984; Grandi et al., 1989; Di Stasi, 1989; Hirschmann \& Arias, 1990; Brandão, 1991; Caribé \& Campos, 1991; Martins et al., 1994; Matos, 1994).

Fungi and bacteria cause important human diseases, especially in tropical regions and in immunocompromised or immunodeficient patients. Despite the existence of potent antibiotic and antifungal agents, resistant or multi-resistant strains are incessantly appearing, imposing the need for search and development of new drugs (Silver \& Bostian, 1993).

In an effort to discover new lead compounds, many research groups screen plant extracts to detect secondary metabolites with relevant biological activities based on ethnopharmacological uses (Bezerra et al., 2006; Funke \& Melzig, 2006; Leitão et al., 2006; Lima et al., 2006; Barbosa-Filho et al., 2007; Saúde-Guimarães \& Faria, 2007; Rodríguez et al., 2008). Byrsonima species are widely distributed throughout "Cerrado" and in the region Northeast of Brazil. Leaves are used against fever and ulcers, including dermal and gastrointestinal diseases (Silva et al., 2001; Lopez et al., 2001; Agra et al., 2007 and 2008). Chemical investigation of species belonging in to this genus resulted in the isolation of steroids, triterpenes, flavonoids, proanthocyanidins and sulphonoglycolipids (Rastrelli et al., 1997; Mendes et al., 1999; Bejar et al., 1995). We have previously reported the isolation and/or identification of quercetin derivatives, galloyl quinic acids, proanthocyanidins besides the dimeric flavonoid amentoflavone and minor amounts of galloyl hexose and galloyl saccharose in the B. crassa leaves extract (Sannomiya et al., 2004; Sannomiya et al., 2005a; Sannomiya et al., 2005b; Sannomiya et al., 2005c). Some biological activities of Byrsonima species have been previously investigated. The methanol and hydromethanol extracts from $B$. basiloba (formerly documented as B. cinera) leaves have presented anti-diarrhea activity (Figueiredo et al., 
2005). The polar extracts of $B$. crassa leaves showed a potential antiulcerogenic effect in mice (Sannomiya et al., 2005a). The methanol extract of B. crassifolia leaves showed strong giardicidal activity (Amaral et al., 2006). The ethyl acetate of B. crassifolia roots was active against Klebsiella pneumoniae, Pseudomonas aeruginosa, Salmonella typhi, Shigella flexneri, Staphylococcus aureus, S. epidermidis, Streptococcus pneumoniae and Micrococcus luteus (Martinéz-Vasquez et al., 1999). The preliminary biological screening indicated that $\mathrm{EMeOH}$ and $\mathrm{EMeOH} 80 \%$, including both the EtOAc and aqueous fractions of $\mathrm{EMeOH}$, showed antimicrobial activity against Staphylococcus epidermidis, Bacillus cereus, B. subtilis, Salmonella sp., Proteus mirabilis, Enterococcus faecalis, Shigella sp. and Candida albicans (Sannomiya et al., 2005c). Despite the popular use of $B$. basiloba, B. intermedia and $B$. fagifolia as medicinal plants, there are no data about the antimicrobial effect of their leaf extracts. Thus, the interest in these plants is justifiable because of their potential medicinal value. The present study has the aim to evaluate the antimicrobial activity of Byrsonima species extracts obtained from the leaves by using the disc-diffusion method.

\section{MATERIAL AND METHODS}

\section{Microorganisms}

Eight microbial species were analyzed, which were taken from international collections. The bacteria Bacillus subtilis (ATCC 9372), Bacillus cereus (ATCC 14579), Shigella spp (IAL 1578), Staphylococcus epidermidis (ATCC 12226), Proteus mirabilis (CDC 305), Salmonella spp (ATCC 19196), Enterococcus faecalis (ATCC 29212), and the yeast Candida albicans (ATCC 10231).

\section{Plant material}

Leaves of Byrsonima fagifolia Niedenzu (IK) were collected by Dr. Clélia A. Hiruma-Lima at Porto Nacional, State of Tocantins, Brazil. The plant was identified by Prof. Dr. Eduardo Ribeiro dos Santos, Department of Botany, Universidade do Tocantins - State of Tocantins, where a voucher specimen was deposited ( ${ }^{\circ}$ 6398). The plant material of Byrsonima basiloba A. Juss. ( $\mathrm{n}^{\circ}$ 24163) and B. intermedia A. Juss. ( $\mathrm{n}^{\circ}$ 24164) were collected by Luiz Fernando Rolim de Almeida at Pratânia, State of São Paulo, Brazil and authenticated by Dr. Clemente José Campos and deposited at the Herbarium of Unesp - Botucatu.

\section{Extract preparation}

The air-dried and powdered leaves of all Byrsonima species were extracted separately and exhaustively with $\mathrm{CHCl}_{3}, \mathrm{MeOH}$ and $80 \% \mathrm{MeOH}$ successively at room temperature ( $48 \mathrm{~h}$ for each solvent). Solvents were evaporated at $60{ }^{\circ} \mathrm{C}$ under reduced pressure affording the extracts coded as $\mathrm{ECHCl}_{3}$, $\mathrm{EMeOH}$ and $\mathrm{EMeOH}$ 80\% (Table 1).

\section{Phytochemical screening}

The chromatographic analyses were made by TLC on Si gel eluted with the mobile phases: $\mathrm{CHCl}_{3}$ / $\mathrm{MeOH}(70: 30, v: v)$ and $\mathrm{CHCl}_{3} / \mathrm{MeOH} / \mathrm{H}_{2} \mathrm{O}(80: 18: 2$, $\mathrm{v} / \mathrm{v})$.

Chromatographic evaluation of the $\mathrm{MeOH}$ and $80 \% \mathrm{MeOH}$ extracts by TLC revealed with NP/PEG (diphenylaminoborate/polyethyleneglycol) reagent (Wagner et al., 1984) produced intense orange and yellow spots characteristic of flavonoids and plates revealed with anisaldehyde/sulfuric acid solution also produced reddish and gray spots, suggesting the presence of catechin derivatives and phenolic compounds, respectively. We also spotted authentic standards (Sigma) of quercetin, myricetin, kaempferol, (+)-catechin, (-)-epicatechin, gallic acid and methyl gallate.

The detection of the tannins were realized according to the proceedings described by Simões et al. (2001) using the reaction the reaction with iron salts Schneider (1990) and with the gelatin.

Iodine vapors and saturated solution of $\mathrm{H}_{2} \mathrm{SO}_{4} /$ $\mathrm{CeSO}_{4}$ (saponins and terpenes) and anisaldehyde/ $\mathrm{H}_{2} \mathrm{SO}_{4}$ solution (flavonoids, terpenes, saponins, gallic acid derivatives and catechins) (Wagner et al., 1984) were also used.

The classes of compounds found in the $\mathrm{EMeOH}$ and $\mathrm{MeOH} 80 \%$ leaves extracts of Byrsonima species are indicated in Table 2.

\section{Disc-diffusion method}

The dried plant extracts of leaves and barks were dissolved in the same solvent $\left(\mathrm{MeOH}\right.$ and $\left.\mathrm{CHCl}_{3}\right)$ to a final concentration of $30 \mathrm{mg} / \mathrm{mL}$. After, they were sterilized by filtration through $0.45 \mu \mathrm{m}$ Millipore filters. Antimicrobial tests were carried out by disc-diffusion method (Bauer et al., 1966).

The microorganism cultures were grown in Brain Heart Infusion liquid medium at $37^{\circ} \mathrm{C}$. After $6 \mathrm{~h}$ of growth, each microorganism culture, at a concentration of $10^{6}$ cells $/ \mathrm{mL}$, was inoculated on the surface of MuellerHinton agar plates $(100 \mu \mathrm{L})$. Subsequently, filter papers discs (6 $\mathrm{mm}$ in diameter) saturated with extracts (20 $\mu \mathrm{L}$ ) were placed on the surface of each inoculated plate, in Brain Heart Infusion solid medium. The plates were incubated at $35{ }^{\circ} \mathrm{C}$ for $24 \mathrm{~h}$ for bacteria and for $48 \mathrm{~h}$ for C. albicans. After this period, the zones of growth inhibition around the discs were measured. Overall, cultured microorganisms with inhibition zones equal to 
or greater than $7 \mathrm{~mm}$ were considered susceptible to the tested extract (Nascimento et al., 2000).

The negative control was the solvent used and the positive control was ciprofloxacin $(5 \mu \mathrm{g} / \mathrm{disc})$ for bacteria and ketoconazole (40 $\mu \mathrm{g} / \mathrm{disc})$ for C. albicans. All determinations were made in duplicate.

\section{Minimum inhibitory concentration}

The minimum inhibitory concentration (MIC) was determined by the dilution method according to National Committee for Clinical Laboratory Standards (NCCLS, 2003). The bacteria were grown in nutrient broth (Brain Heart Infusion liquid medium) for $6 \mathrm{~h}$. After that $20 \mu \mathrm{L}$ of $10^{6}$ cells $/ \mathrm{mL}$ were inoculated in tubes containing nutrient broth supplemented with eight different concentrations $(0.75,1.50,3.0,6.0,12.0,15.0$, 18.0 and $24.0 \mathrm{mg} / \mathrm{mL}$ ) of the extracts. The tubes were incubated at $37^{\circ} \mathrm{C}$ for $24 \mathrm{~h}$ for bacteria and for $48 \mathrm{~h}$, for C. albicans. The lowest concentrations, which did not show any growth of tested organism after macroscopic evaluation were determined as MIC. All determinations were made in duplicate (Nascimento et al., 2000).

\section{RESULTS AND DISCUSSION}

As shown in Table 1, the extracts of the leaves of Byrsonima basiloba, B. intermedia and B. fagifolia were prepared by maceration with chloroform, methanol and hydromethanol solvents.

The results of the phytochemical screening of these species (Table 2) showed the presence of catechins, tannins, gallic acid derivatives and flavonoids in the $B$. basiloba and B. intermedia species. Previously we have reported the isolation of (+)-catechin and quercetin-3-O$\alpha$-L-arabinopyranoside from the $\mathrm{EMeOH}$ of the leaves of B. basiloba (Figueiredo et al., 2005). However, B. fagifolia presented only gallic acid derivatives and flavonoids in its composition. This result confirms those related before with the analytical approach based on the liquid chromatography/electrospray ionization tandem mass spectrometry from the infusion of the $B$. fagifolia. The analysis permitted the detection of five flavonoids glycosides and twenty galloyl quinic acid derivatives (Sannomiya et al., 2007).

In this work were evaluated the antimicrobial activity of all the extracts prepared from these Byrsonima species against seven bacteria and one yeast. The $\mathrm{EMeOH}$ and $\mathrm{EMeOH} 80 \%$ extracts were proved to be good solvents in extracting inhibitory compounds from tested plants. The other hand the $\mathrm{ECHCl}_{3}$ extracts of all species showed inactive against to the microorganisms evaluated.

In the assay against the microorganisms using the agar diffusion method (Table 3), the mean zones of inhibition obtained were between 7 to $14 \mathrm{~mm}$. The MICs values observed was between 1.5 and $12.0 \mathrm{mg} /$ $\mathrm{mL}$. In fact, lowers MIC values were associated with the EMeOH from B. intermedia against E. faecalis $(1.5 \mathrm{mg} /$ $\mathrm{mL})$ and $B$. subtilis $(3.0 \mathrm{mg} / \mathrm{mL})$.

The $\mathrm{EMeOH} 80 \%$ extract of the leaves from $B$. fagifolia showed to be most active against B. cereus, E. faecalis and Shigella with MICs values of $3.0 \mathrm{mg} /$ $\mathrm{mL}$ than $\mathrm{EMeOH}$ with MICs values of 6.0, 7.5 and 6.0, respectively (Table 3). The presence of galloyl quinic acid derivatives on this extract can be responsible to the observed activity. This class of compounds has been recognized as possessing high activity against bronchial hyper-reactivity, allergic reactions, antiherpetic, anti-human immunodeficiency virus (HIV) reverse transcriptase, and anti-HIV activity (Bokech et al., 1996; Nishizawa et al., 1989).

Theses results can be explained based on the larger amount of the galloyl quinic acids derivatives

Table 1. Extracts obtained from Byrsonima species.

\begin{tabular}{l|c|c|c}
\hline \multicolumn{1}{c|}{ Species } & $\mathrm{ECHCl}_{3}(\mathrm{~g})(\mathrm{yield} \%)$ & $\mathrm{EMeOH}(\mathrm{g})(\mathrm{yield} \%)$ & $\mathrm{EMeOH} 80 \%(\mathrm{~g})(\mathrm{yield} \%)$ \\
\hline B. basiloba $(1000 \mathrm{~g})$ & $77.7(7.7 \%)$ & $94.2(9.4 \%)$ & $63.1(6.1 \%)$ \\
B. intermedia $(590 \mathrm{~g})$ & $16.7(2.8 \%)$ & $85.2(14.4 \%)$ & $29.6(5.0 \%)$ \\
B. fagifolia $(1000 \mathrm{~g})$ & $47.3(4.7 \%)$ & $24.6(2.5 \%)$ & $12.9(1.3 \%)$ \\
\hline
\end{tabular}

Table 2. Phytochemical screening of Byrsonima species.

\begin{tabular}{lccccccccc}
\hline \multicolumn{1}{c}{ Test } & \multicolumn{3}{c}{ B. fagifolia } & \multicolumn{3}{c}{ B. basiloba } & \multicolumn{3}{c}{ B. intermedia } \\
\hline & $\mathrm{ECHCl}_{3}$ & $\mathrm{EMeOH}$ & $\begin{array}{c}\mathrm{EMeOH} \\
80 \%\end{array}$ & $\mathrm{ECHCl}_{3}$ & $\mathrm{EMeOH}$ & $\begin{array}{c}\mathrm{EMeOH}^{2} \\
80 \%\end{array}$ & $\mathrm{ECHCl}_{3}$ & $\begin{array}{c}\mathrm{EMeOH} \\
\mathrm{EMeOH} \\
80 \%\end{array}$ \\
\hline Catechins & - & - & - & - & + & + & - & + & + \\
Tannins & - & - & - & - & + & + & - & + & + \\
GAD & - & + & + & - & + & + & - & + & + \\
Flavonoids & - & + & + & - & + & + & - & + & + \\
Saponins & - & - & - & - & - & - & - & - & - \\
Terpenes & + & - & - & + & - & - & + & - & - \\
\hline
\end{tabular}

absent $=(-)$; present $=(+) ; \mathrm{ECHCl}_{3}=$ chloroform extract; $\mathrm{EMeOH}=$ methanol extract; $\mathrm{EMeOH} 80 \%=$ hydromethanol extract; $\mathrm{GAD}=$ gallic acid derivatives. 


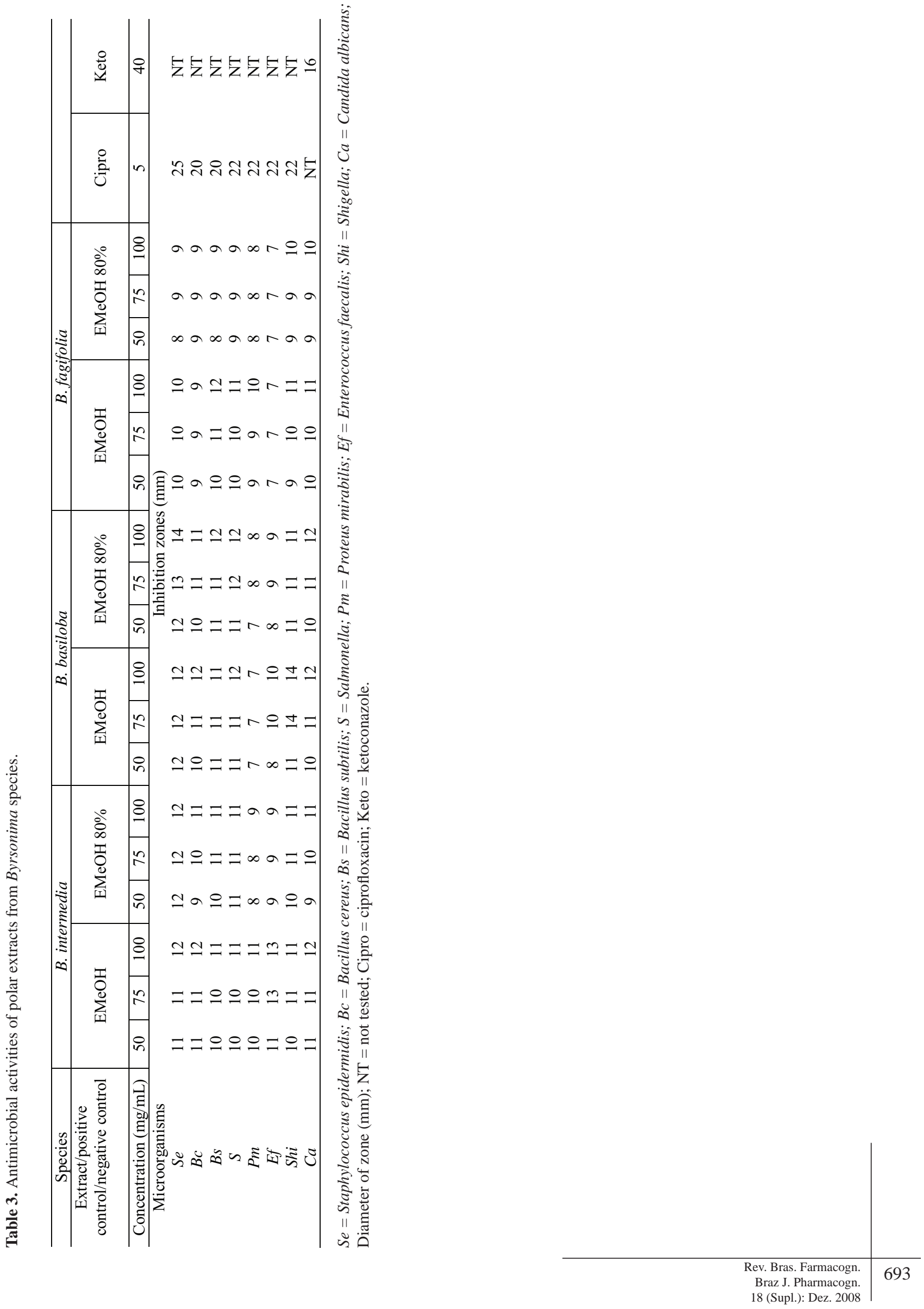


Table 4. Minimum inhibitory concentration (MIC) exhibited by Byrsonima species.

\begin{tabular}{|c|c|c|c|c|c|c|}
\hline \multirow{3}{*}{ Microorganisms } & \multicolumn{6}{|c|}{$\mathrm{MIC}(\mathrm{mg} / \mathrm{mL})$} \\
\hline & \multicolumn{2}{|c|}{ B. basiloba } & \multicolumn{2}{|c|}{ B. intermedia } & \multicolumn{2}{|c|}{ B. fagifolia } \\
\hline & $\mathrm{MeOH}$ & $\begin{array}{c}\mathrm{MeOH} \\
80 \%\end{array}$ & $\mathrm{MeOH}$ & $\begin{array}{c}\mathrm{MeOH} \\
80 \%\end{array}$ & $\mathrm{MeOH}$ & $\mathrm{MeOH} 80 \%$ \\
\hline$S e$ & 6.0 & 6.0 & 6.0 & 6.0 & 6.0 & 6.0 \\
\hline Bs & 6.0 & 6.0 & 3.0 & 7.5 & 6.0 & 6.0 \\
\hline$B c$ & 6.0 & 6.0 & 6.0 & 7.5 & 6.0 & 3.0 \\
\hline$E f$ & 6.0 & 6.0 & 1.5 & 6.0 & 7.5 & 3.0 \\
\hline Shi & 6.0 & 6.0 & 6.0 & 12.0 & 6.0 & 3.0 \\
\hline$P m$ & 9.0 & 7.5 & 9.0 & 7.5 & 6.0 & 6.0 \\
\hline$S$ & 7.5 & 6.0 & 6.0 & 6.0 & 6.0 & 7.5 \\
\hline $\mathrm{Ca}$ & 7.5 & 7.5 & 6.0 & 9.0 & 6.0 & 6.0 \\
\hline
\end{tabular}

Se = Staphylococcus epidermidis; $B c=$ Bacillus cereus; $B s=$ Bacillus subtilis; $S=$ Salmonella; Pm = Proteus mirabilis; Ef = Enterococcus faecalis; Shi = Shigella; $\mathrm{Ca}=$ Candida albicans.

on the EMeOH $80 \%$ than EMeOH. This difference can be expected by the higher polarity of the solvent extraction.

The results appear promising for a possible use of the B. intermedia and B. fagifolia or their components as antimicrobial agents. However, further studies are necessary to evaluate the toxic effects of these extracts.

Further phytochemical studies are in progress to establish which are the compounds responsible for the bioactivity of these medicinal plants and thus ascertain the value of the ethnobotanical approach for the screening of plants as potential sources of bioactive substances.

\section{ACKNOWLEDGEMENTS}

We are grateful to Fundação Amparo à Pesquisa do Estado de São Paulo (FAPESP) for a grant to M.S. and to M.E.F. and for fundings from the Biota-Fapesp Program and to Conselho Nacional de Desenvolvimento Científico (CNPq) for a grant to D.C.M, to H.R.N.S. and to W.V.

\section{REFERENCES}

Agra MF, França PF, Barbosa-Filho JM 2007. Synopsis of the plants known as medicinal and poisonous in Northeast of Brazil. Rev Bras Farmacogn 17: 114140.

Agra MF, Silva KN, Basílio IJLD, França PF, Barbosa-Filho JM 2008. Survey of medicinal plants used in the region Northeast of Brazil. Rev Bras Farmacogn 18: 472-508.

Amaral FMM, Ribeiro MNS, Barbosa-Filho JM, Reis AS, Nascimento FRF, Macedo RO 2006. Plants and chemical constituents with giardicidal activity. Rev Bras Farmacogn 16 (Supl.): 696-720.

Barbosa-Filho JM, Nascimento-Júnior FA, Tomaz ACA, Athayde-Filho PF, Silva MS, Cunha EVL, Souza MFV, Batista LM, Diniz MFFM 2007. Natural products with antileprotic activity. Rev Bras Farmacogn 17: 141-148.

Bauer AW, Kirby MDK, Sherries JC, Truck M 1966. Antibiotic susceptibility testing by a standardized single disk method. Am J Clin Pathol 45: 493-496.

Bejar E, Amarquaye A, Chec C-T, Malone MH, Fong HHS 1995. Constituents of Byrsonima crassifolia and their spasmogenic activity. Int J Pharmacogn 33: 25-32.

Bezerra JL, Costa GC, Lopes TC, Carvalho ICDS, Patrício FJ, Sousa SM, Amaral FMM, Rebelo JMM, Guerra RNM, Ribeiro MNS, Nascimento FRF 2006. Avaliação da atividade leishmanicida in vitro de plantas medicinais. Rev Bras Farmacogn 16 (Supl.): 631-637.

Bokesch HR, McKee TC, Currens MJ, Gulakowski RJ, McMahon JB, Cardellina II JH, Boyd MR 1996. HIVinhibitory gallotannins from Lepidoptrys staudtii. Nat Prod Lett 8: 133-136.

Brandão M 1991. Plantas medicamentosas do cerrado mineiro. Inf Agropec 15: 15-20.

Caribé J, Campos JM 1991. Plantas que Ajudam o Homem: Guia Prático para a Época Atual. São Paulo: Pensamento.

Corrêa MP 1984. Dicionário das Plantas Úteis do Brasil e das Exóticas Cultivadas. Rio de Janeiro: Ministério da Agricultura IBDF.

Di Stasi LC 1989. Plantas Medicinais da Amazônia. São Paulo: Unesp, p. 39-40.

Ferreira MB 1980. Plantas portadoras de substâncias medicamentosas, de uso popular, nos cerrados de Minas Gerais. Inf Agropec 6: 19-23.

Figueiredo ME, Michelin DC, Sannomiya M, Silva MA, Santos LC, Almeida LFR, Souza-Brito ARM, Salgado HRN, Vilegas W 2005. Avaliação química e anti-diarréica das folhas de Byrsonima cinera DC. (Malpighiaceae). Rev Bras Cienc Farm 41: 79-83.

Funke I, Melzig MF 2006. Traditionally used plants in diabetes therapy - phytotherapeutics as inhibitors of $\alpha$-amylase activity. Rev Bras Farmacogn 16: 1-5.

Grandi TSM, Trindade JA, Pinto MJF, Ferreira LL, Catella AC 1989. Plantas medicinais de Minas Gerais. Acta Bot Bras 3: 185-224.

Hirschmann GS, Arias AR 1990. A survey of medicinal plants of Minas Gerais, Brazil. J Ethnopharmacol 29: 159172.

Leitão SG, Castro O, Fonseca EM, Julião LS, Tavares ES, Leo RRT, Vieira RC, Oliveira DR, Leitão GG, Martino V, Sulsen V, Barbosa YAG, Pinheiro DPG, Silva PEA, Teixeira DF, Lourenço MCS 2006. Screening 
of Central and South American plant extracts for antimycobacterial activity by the Alamar Blue test. Rev Bras Farmacogn 16: 6-11.

Lima MRF, Ximenes CPA, Luna JS, Sant'Ana AEG 2006. The antibiotic activity of some Brazilian medicinal plants. Rev Bras Farmacogn 16: 300-306.

Lopez A, Hudson JB, Towers GHN 2001. Antiviral and antimicrobial activities of Colombian medicinal plants. J Ethnopharmacol 77: 189-196.

Martinez-Vasquez M, Gonzalez-Esquinca AR, Cazares-Luna L, Moreno-Gutiierrez MN, Garcìa-Argàez AN 1999. Antimicrobial activity of Byrsonima crassifolia (L.) H.B.K. J Ethnopharmacol 66: 79-82.

Martins ER, Castro DM, Castellani DC 1994. Plantas Medicinais. Viçosa: Imprensa Universitária UFV.

Matos FJA 1994. Farmácias Vivas. Fortaleza: EUFC.

Mendes CC, Cruz FG, David JM 1999. Triterpenos esterificados com ácidos graxos e ácidos triterpênicos isolados de Byrsonima microphylla. Quim Nova 22: 185-188.

Nascimento GGF, Locatelli J, Freitas PC, Silva GL 2000. Antibacterial activity of plant extracts and phytochemicals on antibiotic-resistant bacteria. Braz J Microbiol 31: 247-256.

NCCLS 2003. National Committee for Clinical Laboratory Standards - Performance Standards for Antimicrobial Disc Susceptibility Tests 2003. Approved Standard M2-A7. Pennsylvania: Wayne.

Nishizawa M, Yamagashi T, Dutschman GE, Parker WB, Bodner AJ, Kilkuskie RE, Cheng Y-C, Lee K-H 1989. Anti-Aids agents. 1. Isolation and characterisation of four new tetragalloylquinic acids as a new class of HIV reverse transcriptase inhibitors from tannic acid. J Nat Prod 52: 762-768.

Rastrelli L, De Tommasi N, Berger I, Caceres A, Saravia A, De Simone F 1997. Glycolipids from Byrsonima crassifolia. Phytochemistry 45: 647-650.

Rodríguez M, Hasegawa M, González-Mújica F, Motta N, Castillo A, Castillo J, Zea E, Mora K, Sousa L, González A, Camejo D 2008. Antidiabetic and antiradical activities of plants from Venezuelan Amazon. Rev Bras Farmacogn 18: 331-338.

Sannomiya M, Rodrigues CM, Coelho RG, Dos Santos LC, Hiruma-Lima CA, Souza-Brito ARM, Vilegas W 2004. Application of preparative high-speed counter-current chromatography for the separation of flavonoids from the leaves of Byrsonima crassa Niedenzu (IK). J Chromatogr A 1035: 47-51.

Sannomiya M, Fonseca VB, Da Silva MA, Rocha LRM, Dos Santos LC, Hiruma-Lima CA, Souza-Brito ARM, Vilegas W 2005a. Flavonoids and antiulcerogenic activity from Byrsonima crassa leaves extracts. $J$ Ethnopharmacol 97: 1-6.

Sannomiya M, Montoro P, Piacente S, Pizza C, Souza-Brito ARM, Vilegas W 2005b. Application of liquid chromatography/electrospray ionization tandem mass spectrometry to the analysis of polyphenolic compounds from an infusion of Byrsonima crassa Niedenzu. Rapid Commun Mass Spectrom 19: 22442250.

Sannomiya M, Michelin DC, Rodrigues CM, Dos Santos LC, Salgado HRN, Hiruma-Lima CA, Souza-Brito ARM, Vilegas W 2005c. Byrsonima crassa Niedenzu (IK): antimicrobial activity and chemical study. Rev Cienc
Farm Básica Apl 26: 71-75.

Sannomiya M, Dos Santos LC, Carbone V, Napolitano A, Piacente S, Pizza C, Souza-Brito ARM, Vilegas W 2007. Liquid chromatography/electrospray ionization tandem mass spectrometry profiling of compounds from the infusion of Byrsonima fagifolia Niedenzu. Rapid Commun Mass Spectrom 21: 1393-1400.

Saúde-Guimarães DA, Faria AR 2007. Substâncias da natureza com atividade anti-Trypanosoma cruzi. Rev Bras Farmacogn 17: 455-465.

Schneider G 1990. Arzneidrogen. Ein Kompendium für Pharmazeuten, Biologen und Chemiker. Mannheim:Wissenschaftsverlag.

Silva SR, Silva AP, Munhoz CB, Silva Jr MC, Medeiros MB 2001. Guia de Plantas do Cerrado utilizadas na Chapada dos Veadeiros. Brasília: WWF.

Silver LL, Bostian KA 1993. Discovery and development of new antibiotics: the problem of antibiotic resistance. Antimicrob Agents Chemother 37: 377-383.

Simões CMO, Schenkel EP, Gosmann G, Mello JCP, Mentz LA, Petrovick PR 2001. Farmacognosia, da Planta ao Medicamento. 3. ed, Porto Alegre / Florianópolis: Ed. Universidade/ UFRGS, Ed. da UFSC.

Wagner H, Bladt H, Zgainski EM 1984. Plant Drug Analysis. Berlin: Springer. 